\title{
Notes on breeding sites of Pelecaniformes in Micronesia
}

\author{
J. DE KORTE and H. MELTOFTE
}

During a tourist cruise with M.V. Academik Shokalski from Cairns (Australia) to Chuuk (Micronesia) between 20 March and 3 April 1996 we visited a number of seabird islands in Micronesia described by Nelson (1978). On these and other islands visited, we asked local people for further information on breeding seabirds. After the cruise H.M. visited Ant Atoll at Pohnpei.

This note presents the results. Time did not allow us to undertake real counts so we provide only rough estimates of numbers of breeding pairs, in orders of magnitude.

Black Noddies Anous tenuirostris minutus and Brown Noddies A. stolidus were breeding on most of the atolls that we visited (Kapingamarangi, Nukuoro, Satawan, Namoluk, Lukunor, Ant), and so were small numbers of Black-naped Terns Sterna sumatrana and White Terns Gygis alba

We did not see any colonies with Pelecaniformes in Papua New Guinea, where we visited Samarai, Gawa, Iwa, Nesup, Garove and Kavieng. However, we were told of roosts or breeding sites with frigatebirds Fregata sp. on Baniara in Collingwood Bay and Sabari in the Louisiade Archipelago, and of breeding sites with Brown Boobies Sula leucogaster on Gumatabu and Kwailuia in the Trobriands, and on Cannac Rock in the Laughlans.

The areas visited are not covered by the recent account of oceanic seabirds published by Croxall et al. (1984), Croxall (1991) and Nettleship et al. (1994).

\section{Kapingamarangi Atoll 29 March}

No colonies with Pelecaniformes. Great Frigatebirds Fregata minor roosted on an islet in the south-western part of the atoll.

\section{Nukuoro Atoll 30 March}

On the islet of Oromange, which according to the locals was a rich bird island, we found only two half-grown young of Red-footed Boobies Sula sula together with a quite fresh skin of an adult Red-footed Booby, that apparently had been eaten by locals. One further young (c. 1.5 months old) was tied to a stick in the village, where people said that they collected eggs and young seabirds from Oromange "only now and then'. Many rats were seen on Oromange.

\section{Satawan Islands (Mortlock Islands) 31 March}

On Aliare Island, where Red-footed Boobies were thought to nest (Nelson 1978), no Pelecaniformes were found. The same apparently applies to Lukunor Islands. 
which we did not visit but where people from Satawan did not know of any large seabirds breeding.

\section{Namoluk Atoll (Mortlock Islands) I April}

No Pelecaniformes breeding.

\section{East Fayu Island 2 April}

A rich seabird island, but with signs of depletion. The island, which has no permanent habitation, may be divided into three sections, partly separated by channels. The northern section (I) is forested but with a banana plantation established in the central part about 5 years ago. The middle section (II) is also forested but partly cultivated with coconuts. The southern section (III) is a barren sandflat. Many rats were seen on sections I and II.

About 100-200 pairs of Great Frigatebirds were breeding on section I. Most pairs had half-grown young but also some newly fledged juveniles were seen.

About 500-1000 pairs of Red-footed Boobies were breeding mainly on section I, with only a few pairs on section II. Both colour phases were present. Brown Boobies were breeding, with about 200-500 pairs on section I. Most boobies had half-grown young, but also fledged young and young almost able to fly were seen. Four Masked Boobies Sula dactylatra were roosting on a rock on the reef.

About 500-1000 Sooty Terns Sterna fuscata were flying over the islands. One pair had a full-grown young with a broken but healed wing, whereas no other juveniles were present. Local fishermen considered that other visitors may have broken the wings of all the young in the colony and later collected them as full-grown young.

Two nests of Crested Terns Sterna bergii with one egg each were found on section III besides a pair with one large young on section I. A few White Terns were present on sections I and II. The population of Black Noddies was estimated at a total of at least 10,000 pairs on sections I and II. Apparently, most were pre-breeding, as no eggs or young were seen. More than 1000 pairs of Brown Noddies were estimated to breed on sections I and II. Many juveniles were roosting on section III, where a nest with one egg and nine almost fledged young was also encountered.

According to the son-in-law of the land-owner (who, incidentally stayed on the island together with three relatives) many more birds bred on East Fayu in the past, when people used sail-boats to visit. Nowadays different groups of fishermen visit the island regularly with speedboats to catch sea-turtles and collect eggs and young of seabirds. During the previous day they had caught three Green Turtles Chelonia mydas and on section III we noted that many turtle nests had been dug out by humans.

\section{Ant Atoll (Pohnpei) 7 April}

A fully intact seabird colony was found on Wolona Island in this uninhabited atoll, the owner of which charges $\$ 10$ per visitor. The islet was forested with 
about $80 \%$ cover of Pisonia, 15\% Tournefortia and 5\% Morinda citrifolia, together with about six mature coconut palms (W. Raynor pers. comm.).

Eight Great Frigatebirds roosted on the islet and the species may possibly breed there. One pair of Red-tailed Tropicbirds Phaethon rubricauda was incubating together with about 100 pairs of Sooty Terns. Some 50-100 pairs of Red-footed Boobies generally had half-grown or large young on the islet, whereas only one single Brown Booby was seen. Finally, an estimated 5,00010,000 pairs of Black Noddies had eggs or newly hatched chicks.

\section{Other colonies in Micronesia}

According to Nelson (1978), Red-footed Boobies and frigatebirds breed on Oroluk. We did not visit this atoll but local people from Kapingamarangi, Nukuoro and Hall islands stated that large seabirds are still breeding there, albeit in decreasing numbers.

Also according to Nelson (1978) and local people from Hall Islands seabird colonies are found on Magur and West Fayu. Gaspar Rico had large colonies in the first half of this century (Nelson 1978).

\section{Conservation implications}

That only three more or less intact colonies of larger Pelecaniformes are found in the areas concerned is a vivid demonstration of the poor conditions that many tropical seabird populations face. Similar low and dwindling numbers of colonies are found in the Philippines and Indonesia, where the state of the colonies is as bad as in Micronesia (de Korte 1984, 1991, de Korte and Silvius 1994, Manamtam 1996a).

With their slow population turnover, Pelecaniformes are extremely vulnerable to exploitation and habitat destruction. Their extensive fledging period means that just a few harvests of eggs and young per year can reduce breeding success of a colony significantly. Furthermore, local people do not seem to realize the destruction, because many birds still use the breeding sites as roosts.

Because of their often widespread distribution these species are not immediately endangered by extinction on a global level, but it must be feared that, in a few years, Pelecaniformes may only be breeding in a small number of protected colonies in countries with a well-developed nature conservation infrastructure.

If this negative trend is to be stopped or even reversed, regional conservation programmes must be developed and funded (e.g. Manamtam 1996b). Such programmes must involve local people, who must benefit in some way from the conservation measures. One possibility is that landowners can earn fees paid by visitors, as in Ant Atoll. On East Fayu the destruction of habitat and the harvest of seabirds was closely related to sea-turtle catching, for fishermen only went there to catch turtles but then took the opportunity to collect eggs and birds. Hence, if local fishermen could be persuaded not to take sea-turtles (e.g. by compensation) both seabirds and turtles would be safe. 


\section{References}

Croxall, J. P. (ed.) (1991) Seabird status and conservation: a supplement. Cambridge, U.K.: International Council for Bird Preservation (Tech. Publ. 11).

Croxall, J. P., Evans, P. G. H. and Schreiber, R. W. (1984) Status and conservation of the World's seabirds. Cambridge, U.K.: International Council for Bird Preservation (Tech. Publ. 2).

Korte, J. de (1984) Status and conservation of seabird colonies in Indonesia. Pp 527-545 in J. P. Croxall, P. G. H. Evans and R. W. Schreiber, eds. Status and conservation of the World's seabirds. Cambridge, U.K.: International Council for Bird Preservation (Tech. Pub. 2).

Korte, J. de (1991) Status and conservation of Indonesia's seabird colonies. Pp 225-247 in J. P. Croxall, ed. Seabird status and conservation: a supplement. Cambridge, U.K.: International Council for Bird Preservation (Tech. Pub. 11).

Korte, J. de and Silvius, M. J. (1994) Pelecaniformes in Indonesia: status, recent changes and management. Pp. 77-93 in D. N. Nettleship, J. Burger and M. Cochfeld, eds. Seabirds on islands: threats, case studies and action plans. Cambridge, U.K.: BirdLife International (Conservation Series 1).

Manatam, A. S. (1996a) Survey of seabirds in Tubbataha, Cavili and Cagayancillo, the Sula Sea. Manila: Haribon Foundation.

Manatam, A. S. (1996b) Conservation and management strategy for seabirds in the Sula Sea. Manila: Haribon Foundation.

Nelson, J. B. (1978) The Sulidae. Oxford: Oxford University Press.

Nettleship, D. N., Burger, J. and Cochfeld, M. (eds) (1994) Seabirds on islands; threats, case studies and action plans. Cambridge, U. K.: BirdLife International (Conservation Series 1).

\section{J. de KORTE}

Plancius Foundation, Rapenburgerstraat 109, NL-1011 VL Amsterdam, The Netherlands

\section{HANS MELTOFTE}

BirdLife Denmark, Vesterbrogade 140a, DK-1620 Copenhagen V, Denmark 